УДК 338.242.2:005.336.1:330.101.541

DOI: https://doi.org/10.37320/2415-3583/17.10

Шалений В.А.

кандидат економічних наук, доцент

Одеська наџіональна академія харчових технологій ORCID: http://orcid.org/0000-0003-2671-4776

\title{
ДІАГНОСТИКА ЕКОНОМІЧНОЇ ЕФЕКТИВНОСТІ ДІЯЛЬНОСТІ ВІТЧИЗНЯНИХ ПІДПРИСМНИЦЬКИХ СТРУКТУР: МАКРОЕКОНОМІЧНИЙ АСПЕКТ
}

\begin{abstract}
У статті розглядаються питання оцінки економічної ефективності діяльності суб'єктів господарювання в розрізі окремих їх видів у контексті забезпечення макроекономічної стабільності та стратегічного розвитку економіки. Акиентується увага на особливостях подолання підприємствами різних видів системних кризових явищ. За допомогою аналізу абсолютних значень та динаміки ключових кількісних індикаторів стану економічної системи на всіх ї̈ рівнях охарактеризовано вплив системних ризиків на зазначені структурні елементи, визначено роль малих, середніх та великих підприємств у відновленні стабільного стану економіки та забезпеченні iï сталого розвитку. У процесі аналізу визначено, щзо для досягнення стратегічних иілей як на мікро-, так $i$ на макрорівні має бути забезпечене зростання розміру капітальних інвестицій малого бізнесу, яке, своєю чергою, вимагає розроблення та реалізації дієвих механізмів залучення зовнішнього фінансування.
\end{abstract}

Ключові слова: економічна ефективність, чистий прибуток, додана вартість, капітальні інвестиції, продуктивність праці.

Постановка проблеми. Економічна безпека суспільства, стійкість національної економіки та перспективи ії стратегічного розвитку залежать від багатьох чинників, серед яких провідне місце займають процеси, котрі відбуваються на мікрорівні, а саме в підприсмницькому середовищі. При цьому зазначені вище макроекономічні характеристики визначаються не лише абсолютним рівнем та динамікою відповідних фінансово-економічних показників, як то чистий прибуток, рівень рентабельності діяльності, додана вартість, продуктивність праці, кількість зайнятих, показники інвестиційної активності тощо, а й структурою підприємницького середовища.

Аналіз останніх досліджень і публікацій. Актуальним теоретико-методологічним та практичним питанням діагностики ефективності діяльності підприємств присвятили велику кількість наукових праць закордонні і вітчизняні економісти: Р. Солоу [1], П. Хейне [2], Б. Плишевський [3], П. Почкін [4] та ін. Теоретичні та практичні аспекти діагностики ефективності господарської діяльності підприємств у розрізі окремих напрямів відображено в роботах таких вітчизняних учених-економістів, як Т. Голубєва [5], Т. Касянчук [6], О. Макаренко [7], Є. Сич [8], А. Турило [9], Т. Загорна [10], Т. Якимчук [11]. Водночас недостатньо уваги приділяється впливу рівня ефективності господарської діяльності окремих підприємств на макроекономічний розвиток та можливості за рахунок синергічного ефекту, а також використання різними суб'єктами господарювання притаманних лише їм сильних сторін, прискорення економічного розвитку та досягнення стратегічних цілей національної економіки.

Мета статті полягає в оцінці рівня економічної ефективності діяльності вітчизняних суб'єктів господарювання в розрізі поділу їх на великі, середні та малі, а також визначенні ролі зазначених суб'єктів у забезпеченні макроекономічної стабільності та досягненні стратегічних цілей.
Виклад основного матеріалу. Сьогодні оцінка рівня економічної ефективності діяльності різних суб'єктів підприємницької діяльності $є$ надзвичайно важливою в контексті визначення ролі зазначених суб'єктів для вирішення макроекономічних завдань та забезпечення сталого розвитку усієї національної економіки. У роботі акцент зроблено на поділ підприємницьких структур за розмірами на великі, середні та малі відповідно до положень чинного законодавства [12]. Зазначені підприємницькі структури, незважаючи на те що у цілому мають одну головну мету діяльності, а саме отримання прибутку, характеризуються відмінними один від одного сильними та слабкими сторонами, а тому мають виконувати різні функції на мезо- та макрорівні, що викликає необхідність дослідження їх сучасного стану та проведення відповідного ретроспективного аналізу.

Оцінюючи роль різних підприємницьких структур у забезпеченні макроекономічного розвитку, особливу увагу слід приділити питанням функціонування зазначених суб' єктів в умовах кризових явищ та дії різноманітних ризиків, насамперед системних, оскільки саме у ці періоди перевіряється ефективність структури національної економіки, іiі життєздатність у цілому, а також формуються передумови якісних перетворень в економіці. Загалом чутливість суб'єктів підприємництва до дії різноманітних ризиків визначається багатьма чинниками. Одним із найбільш вагомих є розмір суб' єкта. Така теза є абсолютно логічною, оскільки саме розмір підприємства у цілому визначає його гнучкість та можливість швидкої адаптації до мінливих зовнішніх умов, величину резервів (фінансових, матеріальних, кадрових), необхідних для подолання несприятливих обставин, можливості залучення зовнішніх джерел фінансування тощо [13].

Прикладний характер дослідження зазначених вище процесів передбачає формування комплексу відповідних індикаторів (показників). Як індикатори, які дають змогу не лише оцінити рівень ефективності діяльності окремих суб'єктів підприємництва, а й визначити їхню макроекономічну роль, доцільно вико- 
ристовувати показники прибутку (чистого, до оподаткування), рентабельності діяльності, додану вартість, обсяги реалізованої продукції, інвестиційні витрати.

Динаміку чистого прибутку вітчизняних підприємств як найбільш узагальнюючого показника ефективності діяльності на мікрорівні наведено на рис. 1.

Аналізуючи наведені на рисунку дані, можна відзначити, що кризовий період, початком якого можна вважати кінець 2013 р., усі підприємства зустріли на рівні нульової прибутковості діяльності. Найменш ефективно працювали малі підприємства (-29,4 млрд грн), що й визначило загальне незначне негативне сальдо у цілому по вітчизняних підприємствах (-22,8 млрд грн). У цілому підприємства України виявилися зовсім не готовими до системних кризових явищ, які мали місце в 2014-2015 pр. Так, у 2014 р. загальне падіння чистих прибутків порівняно 32013 р. становило 567,2 млрд грн: загальні збитки підприємств у 2014 р. зупинилися на рівні 590,1 млрд грн. Слід відзначити, що катастрофічне падіння прибутків, що в кінцевому підсумку формалізувалося у значних збитках, відбулося по всіх підприємницьких структурах: збитки великих підприємств у 2014 р. становили 204,5 млрд грн, середніх 206,2 млрд грн, малих - 179,3 млрд грн.

Така зміна прибутковості діяльності дає підстави стверджувати, що саме системні ризики, підсилюючи дію один одного (за рахунок багатоаспектної дії та ефекту мультиплікації) стали причиною цього. Дана теза випливає з того, що унікальні ризики, діючи в межах великої системи (національна економіка) в умовах олігополістичного або конкурентного ринків, не мають істотного впливу на систему в цілому, а реалізація їх на конкретних підприємствах компенсується за рахунок підвищення ефективності діяльності та отримання додаткових вигід іншими суб'єктами господарювання. Порівнюючи динаміку чистих прибутків у 2014 р. в розрізі підприємств, класифікованих за своїми розмірами, можна відзначити, що на малих підприємствах падіння чистих фінансових результатів було набагато меншим, аніж на середніх та великих, що пояснюється більшою гнучкістю перших. Гіпотетично можна припустити, що у разі якщо питома вага малих підприємств була б в
Україні більшою, загальне падіння чистих фінансових результатів було б меншим. А тому державна підтримка розвитку малого бізнесу є не лише засобом збільшення кількості робочих місць та зниження безробіття і соціальної напруги в суспільстві, а й є інструментом нівелювання системних кризових явищ в економіці. 2015 p. став більш інформативним щодо оцінки можливостей підприємств протистояти системним ризикам: у цілому по Україні збитки зменшилися на 216,6 млрд грн, що дає підстави говорити про послаблення дії в економіці системних ризиків та підвищення рівня адаптованості до системних загроз вітчизняних підприємств. У 2016 р. вітчизняним підприємствам у цілому вдалося подолати кризові процеси: загальне сальдо за показником чистого прибутку по Україні вперше з 2013 р. стало позитивним (29,7 млрд грн). Слід відзначити, що динаміка фінансових результатів у 2015-2016 рр. по великих та середніх підприємствах значно краща, ніж по малих. Так, у 2016 р. великі підприємства досягли позитивного сальдо фінансових результатів на рівні 46,8 млрд грн, середні - 15,1 млрд грн, і лише малі залишилися збитковими з від'ємним сальдо на рівні $-32,2$ млрд грн. Таким чином, можна констатувати, що між здатністю ефективно долати системні кризові явища та розміром підприємств у сучасних вітчизняних умовах $є$ пряма залежність. Основна причина цього вбачається у більших можливостях великих та середніх підприємств щодо реалізації антикризових заходів за рахунок значної матеріальної та фінансової бази. Динаміка чистого прибутку в 2017-2019 рр. у цілому аналогічна до динаміки кризового періоду: загальний висхідний тренд за більш високих темпів зростання чистого прибутку по великих і середніх підприємствах та відносно низьких темпів росту чистого прибутку малих підприємств. Отже, можна констатувати, що в умовах України малі підприємства $\epsilon$ більш інертними, ніж великі та середні, що у цілому суперечить їхнім природнім атрибутам та $\epsilon$, на нашу думку, ознакою незавершеності процесу формування малого бізнесу як важливого структурного елементу національної економіки й вимагає впровадження та оптимізації відповідних механізмів державної політики.

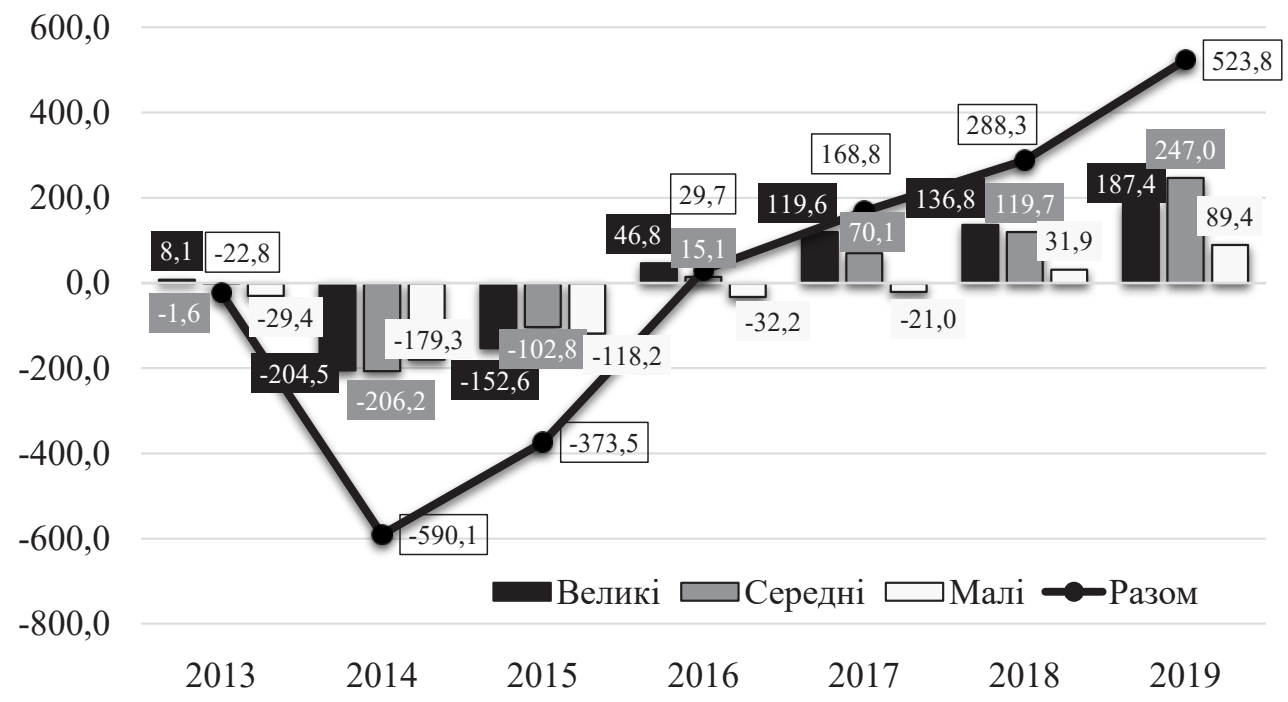

Рисунок 1 - Динаміка чистого прибутку вітчизняних підприсмств, млрд грн 


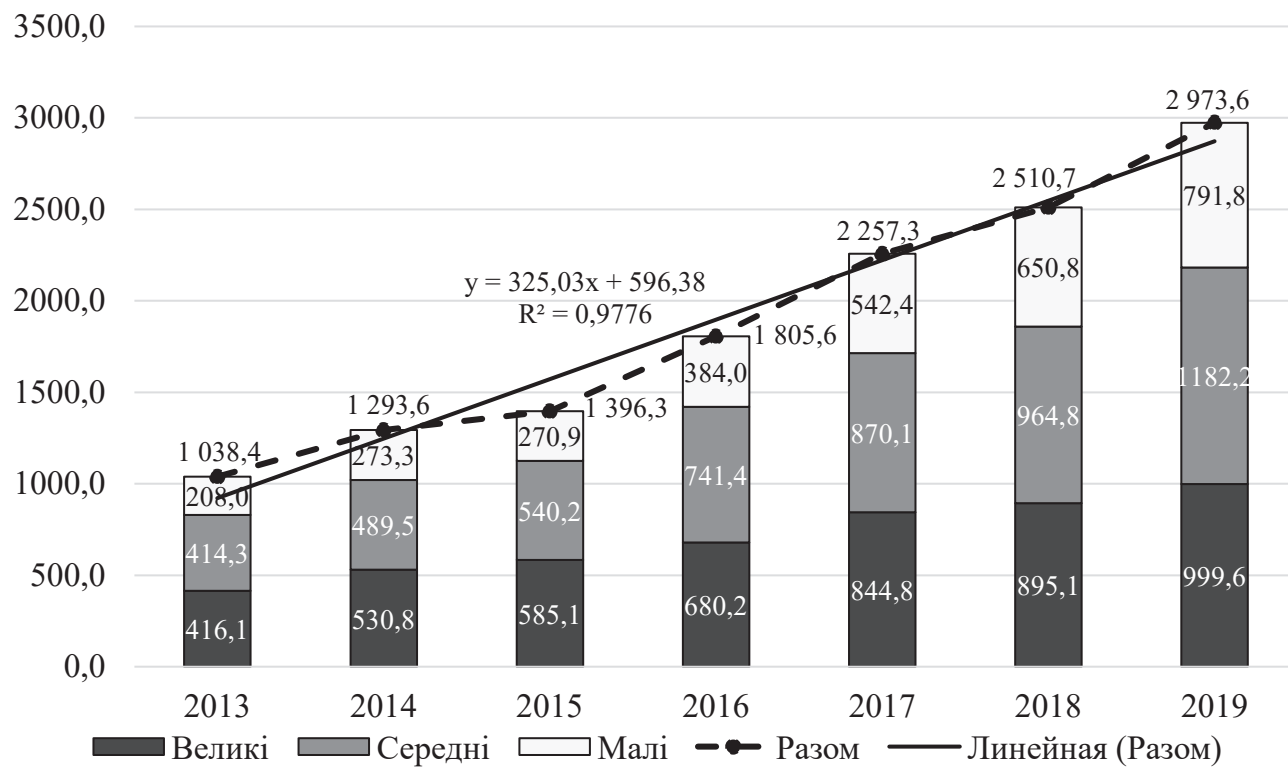

Рисунок 2 - Динаміка доданої вартості вітчизняних підприємств, млрд грн

Важливим показником, який визначає фактичний рівень економічної ефективності та стратегічний потенціал не лише на мікро-, а й макрорівні, є додана вартість. Динаміку доданої вартості суб'єктів підприємницької діяльності, обчислену за витратами виробництва, наведено на рис. 2.

Як свідчать наведені на рисунку дані, протягом 2013-2019 рр. спостерігається стабільна тенденція до загального зростання розміру доданої вартості суб' єктами підприємницької діяльності: щорічне зростання становить у середньому 325 млрд грн. Достовірність отриманого тренду підтверджує значення коефіцієнта детермінації побудованого лінійного рівняння. Заслуговує на увагу той факт, що протягом усього періоду дослідження стабільне зростання доданої вартості спостерігалося по всіх підприємницьких структурах (виняток становили лише малі підприємства в кризовому 2015 р.). Із погляду визначення ролі суб'єктів підприємництва різного виду в забезпеченні макроекономічної стабільності та стратегічного зростання економіки важливим є аналіз структури доданої вартості.
Динаміку структури досліджуваного показника наведено на рис. 3.

Протягом 2013-2019 рр. спостерігається стабільний тренд зростання питомої ваги доданої вартості, яка генерується малими підприємствами (з 20,0\% у 2013 р. до $26,6 \%$ у 2019 р., тобто 6,6\% по структурі) за зворотного скорочення питомої ваги доданої вартості, створюваної великими підприємствами (із 40,1\% у 2013 р. до 33,6\% у 2019 р., що становить 6,5\% по структурі). Питома вага доданої вартості по середніх підприємствах протягом 2013-2019 рр. майже не змінилася і становить 39,8\% у кінці періоду дослідження. Зміни в структурі доданої вартості, яку генерують підприємства різних видів, можуть бути непрямою ознакою перетворень в економічній системі країни: з олігополістичної, орієнтованої на великий бізнес та монополізацію ринків, вона поступово перетворюється на конкурентну, здатну забезпечити багатовекторний розвиток країни та швидку адаптацію до мінливих зовнішніх умов, у тому числі геополітичних. 3 огляду на відсутність протягом 2013-2019 рр. відчутних зрушень щодо запровадження

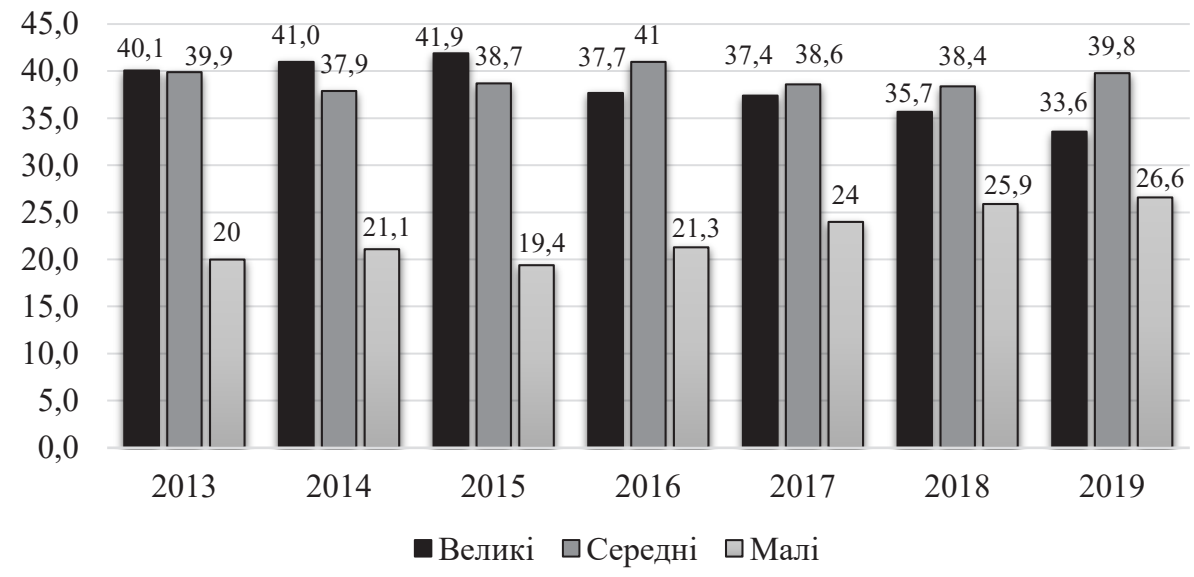

Рисунок 3 - Динаміка структури доданої вартості вітчизняних підприсмств, \% 
дієвих державних механізмів підтримки та активізації розвитку малого бізнесу, зміни у структурі доданої вартості та, відповідно, ролі підприємств різних видів у забезпеченні стратегічного розвитку національної економіки відбулися під впливом внутрішніх рушійних сил, тобто є наслідком об'єктивних економічних процесів.

Із погляду забезпечення стратегічного розвитку окремих суб'єктів господарювання та національної економіки у цілому важливою є оцінка абсолютного рівня та динамки капітальних інвестицій. Являючи собою довгострокові вкладення капіталу в реальні активи, цей показник характеризує не лише рівень поточної ефективності діяльності та можливості підприємницьких структур щодо забезпечення власного розвитку, а й очікування суб'єктів інвестування відносно довгострокових перспектив отримання економічних вигід. Динаміку капітальних інвестицій вітчизняних підприємств наведено на рис. 4.

Наведені на рисунку дані свідчать про зростання капітальних інвестицій у 2013-2019 рр. Так, порівняно 3 кризовим 2014 р. загальний розмір капітальних інвестицій у 2019 р. збільшився майже втричі: зі 178,4 млрд грн до 524 млрд грн. За середньорічного зростання загальної величини інвестицій на 59,1 млрд. грн зростання по великих підприємствах становить 25,3 млрд грн, середніх - 23,3 млрд грн, малих 10,5 млрд грн (результати розрахунків лінійних трендових моделей для капітальних інвестицій по кожному виду підприємств). Якщо не брати до уваги кризовий 2014 р., можна відзначити, що сьогодні для економіки України у цілому характерне стабільне зростання капітальних інвестицій. Слід відзначити, що протягом досліджуваного періоду структура капітальних інвестицій у розрізі видів підприємств, які їх здійснювали, зазнавала відчутних змін. Так, якщо в 2013 р. великі підприємства здійснювали 45,2\% від усіх капітальних інвестицій, то в 2017 р. питома вага капітальних інвестицій великих підприємств зменшилася до 38,8\%, а в 2019 р. знов зросла до 45,8\%. Питома вага інвестицій малих підприємств змінювалася у зворотному напрямі: із 16,2\% у 2013 р. вона зросла до 22,4\% у 2017 р., зменшившись у 2019 р. до 16,1\%. Зміни, які відбувалися у структурі капітальних інвестицій у 2013-2019 рр., на нашу думку, свідчать про наявність значного потенціалу саме малого бізнесу, реалізація якого сьогодні є вкрай ускладненою: ресурсна виснаженість та відсутність довгострокового кредитування як такого призвели до того, що приріст капітальних інвестицій у найкращі періоди, а саме в 2015 (24,0 млрд грн) та 2016 (20,6 млрд. грн) рр. значно скоротився в наступних двох періодах (3,5 млрд грн та 0,5 млрд грн у 2018 та 2019 рр. відповідно). Очевидно, що для досягнення стратегічних цілей як на мікро-, так i на макрорівні має бути забезпечене зростання розміру капітальних інвестицій малого бізнесу в розмірах принаймні на рівні 2015-2016 рр., що, своєю чергою, вимагає розроблення та реалізації дієвих механізмів залучення зовнішнього фінансування. У цьому контексті слід відзначити, що певні кроки на державному рівні вже в процесі реалізації: з 2020 р. реалізується урядова програма доступних кредитів [15].

Важливим показником рівня ефективності господарювання, техніко-технологічного та певною мірою соціального розвитку як на мікро-, так і макрорівні $€$ показник продуктивності праці. Динаміку продуктивності праці, розраховану як відношення обсягів реалізованої продукції (товарів, послуг) до кількості зайнятих, наведено на рис. 5.

Також, як і в разі з іншими показниками ефективності, динаміка продуктивності праці у цілому демонструє позитивну тенденцію до зростання протягом усього періоду дослідження. Середнє зростання продуктивності праці протягом 2013-2019 рр. становить 181,7 тис грн/особу. При цьому якщо по великих підприємствах середньорічні темпи зростання продуктивності праці становлять 283,4 тис грн/особу, то по малих підприємствах - лише 134,9 тис грн. Незважаючи на зростаючий розрив у продуктивності праці між великими та малими підприємствами в абсолютному розмірі, у відносному виразі продуктивність праці на малих підприємствах зростала більшими темпами, ніж на великих. Так, у 2013-2019 pp. загальний темп зростання продуктивності праці по великих підприємствах становив $387 \%$, а по малих - 401\%. Наведена на рисунку динаміка ілюструє переваги великих підприємств, які за рахунок масштабів діяльності за рівнем продуктивності праці є більш конкурентними, ніж малі, що вимагає від останніх активного пошуку шляхів

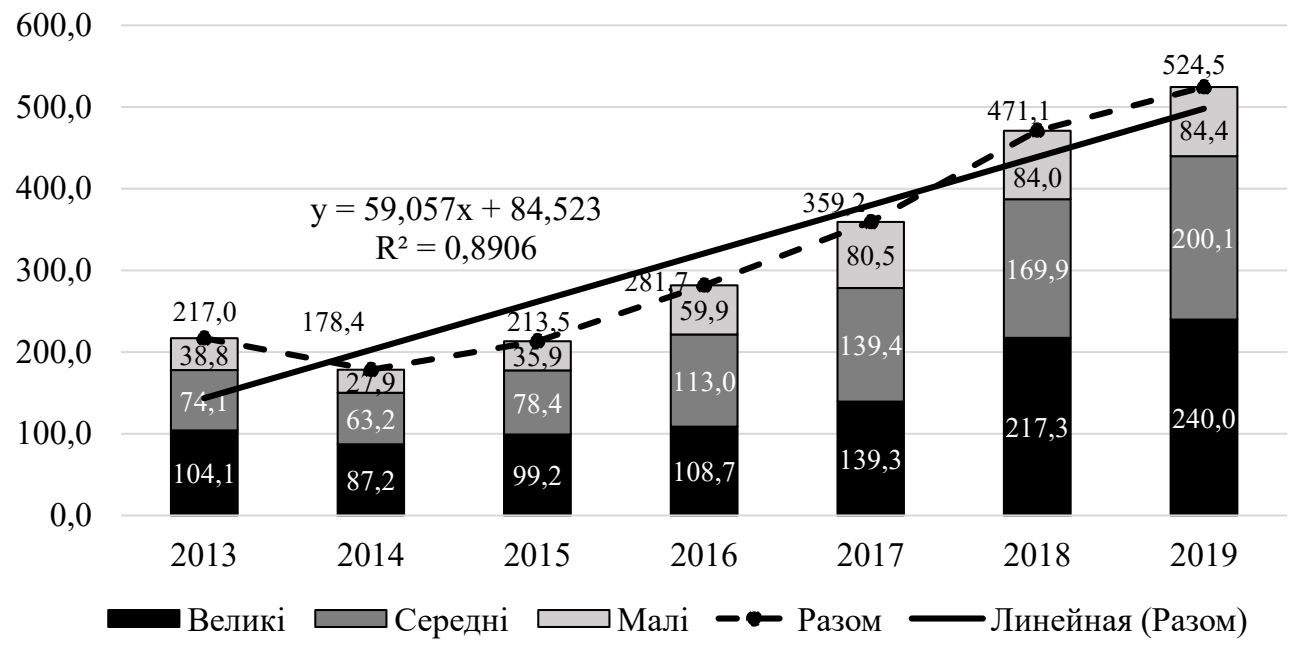

Рисунок 4 - Динаміка капітальних інвестицій вітчизняних підприсмств, млрд. грн 


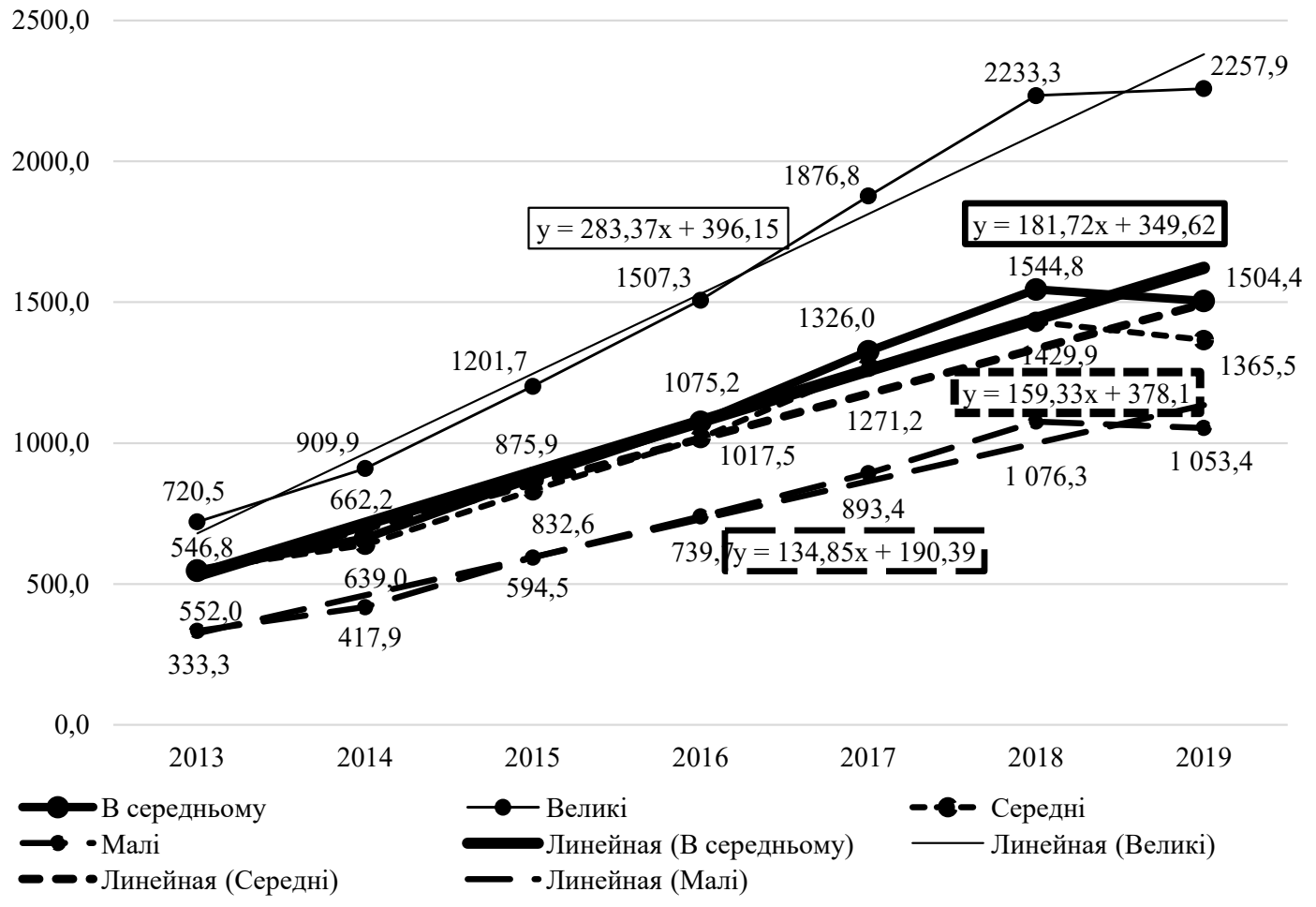

Рисунок 5 - Динаміка продуктивності праці на вітчизняних підприємствах, тис грн/особу

оптимізації господарських процесів, залучення професійних кадрів, здатних до виконання багатозадачних функцій, аутсорсингу тощо.

Висновки. Проведений ретроспективний аналіз показників економічної ефективності діяльності суб' єктів підприємництва, розподілених за розмірами, дав змогу визначити не лише сучасний стан та перспективи розвитку самих суб'єктів, а й оцінити їхню роль у забезпеченні економічної стабільності та стратегічного розвитку усієї національної економіки. У процесі аналізу визначено, що роль підприємств різних видів у забезпеченні сталого розвитку економіки поступово змінюється. Динаміка чистого прибутку як найбільш узагальнюючого показника абсолютного рівня економічної ефективності дає змогу зробити висновок про більший рівень інертності господарських процесів на малих підприємствах, аніж на великих та середніх, що у цілому суперечить їхнім природнім атрибутам та $\epsilon$, на нашу думку, ознакою незавершеності процесу формування малого бізнесу як важливого структурного елемента національної економіки та вимагає впровадження та оптимізації відповідних механізмів державної політики. На основі аналізу динаміки питомої ваги показника доданої вартості, яку генерують підприємства різних видів, може бути зроблений висновок, про значні структурні перетворення в економічній системі країни. Аналіз динаміки капітальних інвестицій вітчизняних підприємств дає змогу зробити висновок, що для досягнення стратегічних цілей як на мікро-, так і на макрорівні має бути забезпечене зростання розміру капітальних інвестицій малого бізнесу, яке, своєю чергою, вимагає розроблення і реалізації дієвих механізмів залучення зовнішнього фінансування.

\section{Список використаних джерел:}

1. Solow R.M. Growth Theory: An Exposition. Oxford University Press, USA ; 2nd ed. 2000. 224 p.

2. Хейне П. Экономический образ мышления / пер. с англ. 10-го изд. Москва : Вильямс, 2007. 544 с.

3. Эффективность общественного производства: критерии, методы расчета, показатели / под ред. Б.П. Плышевского. Москва : Экономика, 1976. 215 с.

4. Почкин П.Ф. Эффективность и интенсивность производства. Москва, 1990. 43 с.

5. Голубєва Т.С., Колос І.В. Методологічні підходи до оцінки ефективності діяльності підприємства. Актуальні проблеми економіки. 2006. № 5(59). С. 66-71.

6. Косянчук Т.Ф., Галкіна Ю.Г. Результативність діяльності підприємства та їі діагностика. Вісник Хмельницького національного університету. 2009. № 3. Т. 1. С. 121-124.

7. Макаренко О.І. Критерії економічної ефективності роботи підприємства в умовах антикризового управління. Актуальні проблеми економіки. 2006. № 7. С. 121-125.

8. Сич С.М., Хотько Т.В. Діагностика ефективності діяльності підприємства. Проблеми підвищення ефективності інфраструктури. 2012. Вип. 34. 182 с.

9. Турило А.М., Турило А.А. Оцінка результативності ефективності продуктивності і збитковості підприємства : монографія. Кривий Ріг : Етюд Сервіс, 2010. 196 с.

10. Загорна Т.О. Економічна діагностика : навчальний посібник. Київ : Центр навч. літ-ри, 2007. 400 с.

11. Якимчук Т.В. Соціально-економічна ефективність підприємства та їі значення в сучасних умовах. URL: http://eztuir.ztu.edu.ua/ handle/123456789/4695; jsessionid= B50C9190611094C205288464EFD2E9FE (дата звернення: 26.03.2021). 
12. Господарський кодекс України. База даних «Законодавство Украӥни». URL: https://zakon.rada.gov.ua/laws/show/ 436-15\#Техt (дата звернення: 27.03.2021).

13. Соколовська О.Г., Шалений В.А. Аналіз сучасного стану зовнішнього середовища підприємств хлібопекарської галузі в контексті оцінки ризикованості їхньої діяльності: макро- та мезорівень. Бізнес-навігатор. 2018. Вип. 5(48). С. 93-101.

14. Державна служба статистики України. URL: http://www.ukrstat.gov.ua/ (дата звернення: 29.03.2021).

15. Державна програма. Доступні кредити 5-7-9\%. URL: https://5-7-9.gov.ua/ (дата звернення: 30.03.2021).

\section{References:}

1. Solow R.M. (2000) Growth Theory: An Exposition. Oxford University Press, USA.

2. Khejne P. (2007) Ekonomicheskij obraz myshleniya [Economic image of thinking]. Moscow: Vilyams. (in Russian)

3. B.P. Plyshevskiy (ed.) (1976) Effektivnost' obshchestvennogo proizvodstva: kriterii, metody rascheta, pokazateli [Efficiency of social production: criteria, calculation methods, indicators]. Moscow: Ekonomika. (in Russian)

4. Pochkin P.F. (1990) Effektivnost' i intensivnost' proizvodstva [Efficiency and intensity of production]. Moscow. (in Russian)

5. Holubyeva T.S., Kolos I.V. (2006) Metodolohichni pidkhody do otsinky efektyvnosti diyal'nosti pidpryyemstva [Methodological approaches to assessing the efficiency of the enterprise]. Actual problems of the economy, no. 5(59), pp. 66-71.

6. Kosyanchuk T.F., Halkina Y.H. (2009) Rezul'tatyvnist' diyal'nosti pidpryyemstva ta yiyi diahnostyka [Effectiveness of the enterprise and its diagnostics]. Bulletin of Khmelnytsky National University, no. 3, vol. 1, pp. 121-124.

7. Makarenko O.I. (2006) Kryteriyi ekonomichnoyi efektyvnosti roboty pidpryyemstva v umovakh antykryzovoho upravlinnya [Criteria for economic efficiency of the enterprise in conditions of anti-crisis management]. Actual problems of the economy, no. 7, pp. 121-125.

8. Sych Ye.M., Khot'ko T.V. (2012) Diahnostyka efektyvnosti diyal'nosti pidpryyemstva [Diagnostics of the efficiency of the enterprise]. Problems of Infrastructure Improvement: Collection of scientific works, vol. 34, pp. 182.

9. Turylo A.M., Turylo A.A. (2010) Otsinka rezul'tatyvnosti efektyvnosti produktyvnosti i zbytkovosti pidpryyemstva [Estimation of the effectiveness of performance efficiency and losses of the enterprise]. Kriviy Rig: Etude Service. (in Ukrainian)

10. Zahorna T.O. (2007) Ekonomichna diahnostyka [Economic diagnostics]. Kyiv: Center for educational literature. (in Ukrainian)

11. Yakymchuk T.V. (2011) Sotsial'no-ekonomichna efektyvnist' pidpryyemstva ta yiyi znachennya $v$ suchasnykh umovakh [The socio-economic efficiency of the enterprise and its significance in modern conditions]. Available at: http://eztuir.ztu.edu.ua/ handle/123456789/4695; jsessionid=B50C9190611094C205288464EFD2E9FE (accessed 26 March 2021).

12. Hospodars'kyy kodeks Ukrayiny (2003) [Economic Code of Ukraine]. Available at: https://zakon.rada.gov.ua/laws/ show/436-15\#Text (accessed 27 March 2021).

13. Sokolovs'ka O.H., Shalenyy V.A. (2018) Analiz suchasnoho stanu zovnishn'oho seredovyshcha pidpryyemstv khlibopekars'koyi haluzi v konteksti otsinky ryzykovanosti yikhn'oyi diyal'nosti: makro- ta mezoriven' [Analysis of the current state of the external environment of enterprises of the baking industry in the context of the risk assessment of their activities: macro- and meso levels]. Business Navigator: Scientific and Production Magazine, vol. 5(48), pp. 93-101.

14. Derzhavna sluzhba statystyky Ukrayiny (2020) [State Statistics Service of Ukraine]. Available at: http://www.ukrstat.gov.ua/ (accessed 29 March 2021).

15. Derzhavna prohrama. Dostupni kredyty 5-7-9\% (2020) [State Program. Loans are available 5-7-9\%]. Available at: https://5-7-9.gov.ua/ (accessed 29 March 2021).

Shaleny Volodymyr

Odessa National Academy of Food Technologies

\section{DIAGNOSTICS OF ECONOMIC EFFICIENCY OF DOMESTIC BUSINESS STRUCTURES: MACROECONOMIC ASPECT}

Diagnostics of economic efficiency of business entities in the context of individual types has an important theoretical and practical significance not only on micro-level, but also an important tool for informational support for decision making in the process of providing macroeconomic stability and strategic development of the economy. The article emphasizes the peculiarities of overcoming by enterprises of various types of systemic crisis phenomena. By analyzing the absolute values and dynamics of key quantitative indicators of the state of the state's economic system at all its levels, the influence of systemic risks on these structural elements is characterized, the role of small, medium and large enterprises in restoring the stable state of the economy and its sustainable development are characterized. In the process of analysis, it is determined that the role of enterprises of various types in ensuring the development of the national economy is gradually changing. The assessment of absolute values and dynamics of net profit of enterprises of different types allowed to conclude that the inertia of economic processes in small enterprises than on other entities, which in general contradicts their natural attributes and is a sign of the incomplete process of small business formation as an important structural element of the national element. Economics and requires the introduction and optimization of relevant state policy mechanisms. Analysis of the dynamics of capital investments of domestic enterprises allows us to conclude that in order to achieve strategic goals, both micro and macro level should be equipped with an increase in capital investment in small business, which in turn requires the development and implementation of effective mechanisms for attracting external financing. Based on the analysis of the dynamics of the specific value of the value added indicator, which generates various types of enterprises, it is determined that there are significant structural transformations in the country's economic system: from an oligopolistic, large business and monopolization of markets, it gradually acquires a rice of competitive, capable of providing a multi-vector development of the country. and prompt adaptation to change in external conditions.

Key words: economic efficiency, net profit, added value, capital investment, labor productivity.

JEL classification: D04, D43, M21 